\title{
Effects of topsoil loss on wheat productivity in dryland zones of Chile
}

\author{
N. Brunel ${ }^{1 *}$, F. Meza' 2 R. Ros ${ }^{3}$, F. Santibáñez \\ ${ }^{1}$ Centro de Desarrollo para el Secano Interior, Universidad Católica del Maule, Talca, Chile. ${ }^{2}$ Universidad del \\ Mar, Sede Centro-Sur, Chile. ${ }^{3}$ Facultad de Ciencias Agrarias y Forestales, Universidad Católica del Maule, \\ Talca, Chile. ${ }^{4}$ Centro de Agricultura y Medio Ambiente, Universidad de Chile, Santiago, Chile. *Correspon- \\ ding author:nbrunel@ucm.cl
}

\begin{abstract}
Considering that the most important processes of biogeochemical cycles occur in the upper first centimetres of the soil, minor degrees of erosion may affect crop productivity, especially in the case of low input dryfarming production systems, which dominate the central coastal areas of Chile. The purpose of this study was to evaluate the effect of topsoil loss on wheat productivity in dryfarming areas with Mediterranean climates in Central Chile. The experiment was conducted on a Chilean Alfisol (Pencahue; $35^{\circ} 18^{\prime} 53^{\prime \prime} \mathrm{S}$ and $71^{\circ} 53^{\prime} 40^{\prime \prime} \mathrm{W}$ ), and the topsoil of this soil was progressively removed from a depth of 2 to $18 \mathrm{~cm}(2,6,10,14$ and $18 \mathrm{~cm})$. Once the plots $\left(25 \mathrm{~m}^{2}\right)$ were prepared, winter wheat (Triticum aestivum L.; cultivar Pandora-INIA) was sown by applying the traditional techniques of the zone. A design was established on randomised blocks with six treatments and three replications. After one growing season, the results showed significant differences $(p<0.05)$ in grain yield $\left(\mathrm{kg} \mathrm{ha}^{-1}\right)$ between the control treatment $\left(\mathrm{T}_{0}\right)$ and the treatment with 18 $\mathrm{cm}$ of soil removed $\left(\mathrm{T}_{18}\right)$ with productivity decreasing by $35 \%$. Furthermore, most of the considered productivity parameters were negatively correlated with the depth of soil removed. The results highlighted the importance of topsoil fertility and depth in crop yield.
\end{abstract}

Keywords: soil erosion, topsoil depth, desurfacing, Mediterranean climate. 


\section{Introduction}

Wheat (Triticum spp.) is one of the main crops in dryland areas worldwide. In Chile, approximately $70 \%$ of wheat crops are established in areas with an arid to subhumid Mediterranean climate, which has an important role in the rural economies of broad areas (Mellado, 2007). Most wheat growing areas are established on granitic soils, mainly in the coastal mountain areas of Central Chile, and $63 \%$ of these soils are undergoing severe erosion processes (Pérez and González, 2001). Soil degradation is a consequence of decades of dryfarming slope cultivation of cereals and overgrazing. Thus, many areas of soil have lost their surface horizon and fertility, which has led to a dramatic drop in wheat productivity and has reduced the income of poor rural populations.

The intensive tillage of these fragile soils has triggered a process of degradation characterised by critical surface erosion, which degrades the upper horizons and affects the topsoil depth and properties, thereby, reducing their productive potential (Thompson et al., 1991; Izaurralde et al., 2006). Nonetheless, intensive production practices conceal the immediate effects of soil degradation, which makes early symptoms imperceptible or undetectable by simple observation (Flörchinger et al., 2000; Malhi et al., 1994; Bakker et al., 2004; Fenton et al., 2005; Larney et al., 2009). During the erosion process in cultivated soils, the depth of the Ap horizon decreases and clay content increases as a consequence of mixing with finer particles from lower horizons due to tillage. In addition to being rich in clays, this material has low levels of organic matter, and these characteristics are then transferred to the new upper horizon during erosion (Frye et al., 1982; Christensen and McElyea, 1988). Furthermore, the loss of topsoil is followed by an increase in bulk density, structural deterioration and alteration of the total po- rosity with various suppressing effects on crop yield (Gollany et al., 1992; Malhi et al., 1994).

The depth of topsoil has proven to be a significant parameter in determining soil quality and land productivity. However, changes in the properties of this horizon may produce unexpected crop responses because of a combination of indirect effects (Power $e t$ al., 1981; Mielke and Schepers, 1986; Christensen and McElyea, 1988; Larney et al., 1995). Properties of the soil profile and interaction of different processes generate a complex system influencing crop behaviour. Thus, it is not always possible to apply a simple and universal quantitative relationship to topsoil thickness and crop productivity (Gollany et al., 1992). Some authors have established linear and nonlinear relationships between crop productivity and topsoil degradation, and they have suggested that not all soils behave similarly with respect to erosion processes (Hairston et al., 1988; Larney et al., 1995; Larney et al., 2000). The effect of soil loss may be explained with changes in the chemical and/or physical characteristics of the soil and by its interactions that impact crop production (Christensen and McElyea, 1988; Izaurralde et al., 2006; Thompson et al., 1991).

One method commonly used to evaluate the effects of erosion on productivity is the removal of topsoil or "desurfacing". This technique simulates an erosive phenomenon, but the negative effects of this approach may be exaggerated because of the abruptness of the disturbance (Larney et al., 2000; Bakker et al., 2004). To overcome this limitation and to allow for more realistic results, these authors have proposed the removal of small amounts of soils in continuous intervals over a long period of time. In agricultural areas with degraded soils and limited access to technology, slight levels of soil loss can result in a negative tendency of crop productivity. The objective of 
this experiment was to evaluate the decline of winter wheat (Triticum aestivum L.) productivity as a consequence of topsoil loss in a dryfarming system located in the subhumid Mediterranean climate area of the Maule Region in Chile.

\section{Materials and methods}

\subsection{Characterisation of the study site}

To determine the effect of topsoil removal on wheat productivity, a field trial was conducted during the
2008-2009 season in the locality of Pencahue, Maule Region, Chile ( $35^{\circ} 18^{\prime} 53^{\prime \prime} \mathrm{S}$ and $71^{\circ} 53^{\circ} 40^{\prime \prime} \mathrm{W}$ ). The site is within an agroecological zone of interior dryland with a temperate subhumid Mediterranean climate, an annual average rainfall of $648 \mathrm{~mm}$, a maximum average temperature of $32.6{ }^{\circ} \mathrm{C}$ and a minimum annual average temperature of $5.5^{\circ} \mathrm{C}$ (CIREN, 1997). The average ground elevation reaches up to $207 \mathrm{~m}$ a.s.l., and the average slope is less than $3 \%$. Rainfall distribution during the crop season is shown in Table 1.

Table 1. Rainfall during growing season (2009).

\begin{tabular}{lccccccccc}
\hline Month & May & June & July & August & September & October & November & December & Total \\
\hline $\begin{array}{l}\text { Rainfall } \\
(\mathrm{mm})\end{array}$ & 77 & 126 & 53 & 107 & 31 & 41 & 22 & 0 & 457 \\
\hline
\end{tabular}

The soil at the site is an Alfisol, which is classified as a fine, mixed, and thermic Mollic Palexeralfs (Pocillas Asociacion) (CIREN, 1997), and it has a sandy clay loam texture and subangular blocky structure in the upper horizon. The site is located in a valley bottom positioned on alluvial-colluvial deposits. The following four horizons are recognised in the profile: Ap (0-17 cm; 10 YR 4/2 in moist conditions); $\mathrm{Bw}_{1}$ $(18-35 \mathrm{~cm} ; 7.5$ YR $4 / 4$ in moist conditions with the presence of mottles); $\mathrm{Bw}_{2}$ (36-95 cm; $10 \mathrm{YR} 3 / 2$ in moist conditions with $30 \%$ mottles) and $\mathrm{BC}$ (96-120 cm; 7.5 YR 4/4 in moist conditions to 7.5 YR 4/2 in moist conditions with a reduced presence of mottles). Topsoil characteristics prior to desurfacing based on six subsamples randomly selected within each plot (Table 2) were determined by soil analysis using the methodologies described by Sadzawka et al. (2006).
Table 2. Chemical properties of untreated topsoil $(0-20 \mathrm{~cm})$.

\begin{tabular}{lc}
\hline Properties & Value \\
\hline Total N $\left(\mathrm{mg} \mathrm{kg}^{-1}\right)$ & 4 \\
$\mathrm{P}\left(\mathrm{mg} \mathrm{kg}^{-1}\right)$ & 5 \\
$\mathrm{~K}\left(\mathrm{mg} \mathrm{kg}^{-1}\right)$ & 81 \\
Organic matter $(\%)$ & 1.28 \\
$\mathrm{pH}$ & 5.51 \\
$\mathrm{Mn}\left(\mathrm{mg} \mathrm{kg}^{-1}\right)$ & 6.10 \\
$\mathrm{Zn}\left(\mathrm{mg} \mathrm{kg}^{-1}\right)$ & 0.56 \\
$\mathrm{Cu}\left(\mathrm{mg} \mathrm{kg}^{-1}\right)$ & 2.93 \\
$\mathrm{Fe}\left(\mathrm{mg} \mathrm{kg}^{-1}\right)$ & 44.02 \\
$\mathrm{~B}\left(\mathrm{mg} \mathrm{kg}^{-1}\right)$ & 0.24 \\
$\mathrm{Ca}\left(\mathrm{cmol} \mathrm{kg}^{-1}\right)$ & 7.21 \\
$\mathrm{Mg}\left(\mathrm{cmol} \mathrm{kg}^{-1}\right)$ & 2.04 \\
\hline
\end{tabular}




\subsection{Field methods and yield parameter determination}

In November 2008, 18 plots ( $5 \mathrm{~m}$ x $5 \mathrm{~m}$ ) were created by removing increasingly thicker topsoil layers as follows: 2, 6, 10,14 and $18 \mathrm{~cm}\left(\mathrm{~T}_{2}\right.$ to $\mathrm{T}_{18}$ treatments). Furthermore, a control treatment $\left(\mathrm{T}_{0}\right)$ with unaltered soil was established. The removal of the first $2 \mathrm{~cm}$ of soil was done manually, and the remaining treatments were set mechanically using a skid steer loader (Bobcat brand, model S130, USA). The soil was kept under traditional fallow until May 2009, and it was then prepared with a Honda rototiller (model F600). An equivalent seed dose of $220 \mathrm{~kg} \mathrm{ha}^{-1}$ per plot of Triticum aestivum (Variety Pandora-INIA) was scattered without fertiliser application. In late July, soil macro- and micronutrients were analysed from samples taken at a $0-20 \mathrm{~cm}$ depth after the soil was removed for all six treatments using methodologies previously described by Sadzawka et al. (2006). At the time of physiological maturity, the wheat was harvested at ground level, and samples were collected from an area of one $\mathrm{m}^{2}$ at the centre of each plot. A sample of 50 spikes was oven-dried at $70{ }^{\circ} \mathrm{C}$ for $48 \mathrm{~h}$ and then weighed. Dry weight was used to determine grain yield $\left(\mathrm{kg} \mathrm{ha}^{-1}\right)$, biomass yield $\left(\mathrm{kg} \mathrm{ha}^{-1}\right)$, 1000 grain weight $(\mathrm{g})$, spikes $\left(\mathrm{m}^{-2}\right)$ and grains per spike. Furthermore, a complete grain analysis was carried out using the methodologies described by Sadzawka et al. (2001).

\subsection{Experimental design and statistical analysis}

The experimental design was based on randomised blocks with six treatments (five levels of soil removal plus a control without soil removal) with three replications. Analysis of variance was performed to determine if there was an effect of soil removal on the considered target variables. Comparison of means was performed according to Tukey's test using IBM SPSS v. 18 software.

\section{Results and discussion}

The results obtained for the first growing season showed a proportional decreasing trend in wheat yield according to the different levels of soil removed with major differences between $\mathrm{T}_{0}$ and $\mathrm{T}_{18}$ as shown by the analysis of variance (Tables 3 and 4). Grain yield $\left(\mathrm{kg} \mathrm{ha}^{-1}\right)$ was significantly reduced in proportion to the level of topsoil removal $(p<0.05)$. Similarly, the 1000 grain weight and grains per spike parameters decreased with increasing soil removal, and biomass yield showed no significant difference among treatments (Table 3). These results differed from those obtained by Izaurralde et al. (2006) who demonstrated marked effects on total dry matter yield according to simulated erosion levels. Nevertheless, in areas with arid to subhumid Mediterranean climate, such as in the coastal mountains of Central Chile, the rainfall distribution showed a marked peak between May and August (Table 1) followed by a sharp decrease in spring, thus, limiting soil water availability during the grain filling period, and this climatic condition affected grain yield more than total biomass production. 
Table 3. ANOVA for target production parameters.

\begin{tabular}{lcccc}
\hline Parameters & Sum squares & Dof & Quadratic means & Sig. \\
\hline Biomass $\left(\mathrm{kg} \mathrm{ha}^{-1}\right)$ & 3402824 & 5 & 680564 & .095 \\
Grain yield $\left(\mathrm{kg} \mathrm{ha}^{-1}\right)$ & 457260 & 5 & 91452 & .000 \\
Harvest index & 0.007 & 5 & .001 & .494 \\
1000 grain wg $(\mathrm{g})$ & 37.387 & 5 & 7.4 & .000 \\
Spikes m- $^{2}$ & 35428.484 & 5 & 7085 & .208 \\
Grain m- $^{2}$ & 1836273 & 5 & 367254 & .001 \\
Number of grains per spike $_{\text {Grain weight per spike }(\mathrm{g})}^{135.350}$ & 5 & 27 & .005 \\
\hline
\end{tabular}

(Sig. $<0.05$ means significant difference.)

Table 4. Effect of topsoil removal on productivity parameters of winter wheat (Triticum aestivum; cultivar Pandora-INIA).

\begin{tabular}{lccccc}
\hline $\begin{array}{l}\text { Treatment } \\
(\mathbf{c m})\end{array}$ & $\begin{array}{c}\text { Grain yield } \\
\left.\mathbf{( k g ~ h a}^{-1}\right)\end{array}$ & $\begin{array}{c}\mathbf{1 0 0 0} \text { grain } \\
\mathbf{w g} \mathbf{( g )}\end{array}$ & $\begin{array}{c}\text { Grain } \\
\mathbf{m -}^{\mathbf{2}}\end{array}$ & $\begin{array}{c}\text { Grain number per } \\
\text { spike }\end{array}$ & $\begin{array}{c}\text { Grain weight } \\
\text { per Spike (g) }\end{array}$ \\
\hline $\mathrm{T} 0$ & $1176 \mathrm{a}$ & $41.2 \mathrm{a}$ & $2853 \mathrm{a}$ & $15 \mathrm{a}$ & $0.62 \mathrm{a}$ \\
$\mathrm{T} 2$ & $1046 \mathrm{ab}$ & $42.2 \mathrm{a}$ & $2478 \mathrm{ab}$ & $10 \mathrm{a}$ & $0.44 \mathrm{ab}$ \\
$\mathrm{T} 6$ & $1095 \mathrm{ab}$ & $40.7 \mathrm{ab}$ & $2693 \mathrm{ab}$ & $10 \mathrm{a}$ & $0.40 \mathrm{~b}$ \\
$\mathrm{~T} 10$ & $1080 \mathrm{ab}$ & $40.5 \mathrm{ab}$ & $2664 \mathrm{ab}$ & $9 \mathrm{a}$ & $0.37 \mathrm{~b}$ \\
$\mathrm{~T} 14$ & $852 \mathrm{ab}$ & $39.0 \mathrm{bc}$ & $2181 \mathrm{ab}$ & $7 \mathrm{ab}$ & $0.28 \mathrm{~b}$ \\
$\mathrm{~T} 18$ & $770 \mathrm{~b}$ & $37.8 \mathrm{c}$ & $2032 \mathrm{~b}$ & $8 \mathrm{~b}$ & $0.30 \mathrm{~b}$ \\
\hline
\end{tabular}

Measured values accompanied by different letters in the same column indicate significant differences according to Tukey's test $(p<0.05)$.

Significant differences $(p<0.05)$ in grain yield $\left(\mathrm{kg} \mathrm{ha}^{-1}\right)$ between $\mathrm{T}_{0}$ and $\mathrm{T}_{18}$ (Table 4) were observed. The removal of $18 \mathrm{~cm}$ of topsoil reduced grain yield by $35 \%$ as compared with $\mathrm{T}_{0}$. This result was similar to the $39 \%$ reduction obtained by Larney et al. (2000) for 15 $\mathrm{cm}$ of topsoil removal and $44 \%$ reduction obtained by Tanaka and Aase (1989). These authors also observed a decrease in grain nitrogen content, which differed from the results obtained by Izaurralde et al. (2006) and those observed in this study where the amount of $\mathrm{N}$ increased by $18 \%$ in the wheat grain for $\mathrm{T}_{18}$ as compared with $\mathrm{T}_{0}(1.13$ vs. $1.38 \%)$. This observation may be a consequence of lower grain weight and production, which result in the concentration of nitrogen compounds. The other analysed nutrients in the wheat grain showed no significant differences among treatments. The decrease in grain yield was closely related to grain weight, and this last parameter was that most affected by soil removal with a high level of correlation $\left(\mathrm{R}^{2}=0.71\right)$. The results showed a reduction in grain weight by $6.5 \%$ on average between both $\mathrm{T}_{14}$ and $\mathrm{T}_{18}$ with respect to $\mathrm{T}_{0}$, and these results were in agreement with those obtained by Izaurralde et al. (2006). 
The values for grain yield $\left(\mathrm{kg} \mathrm{ha}^{-1}\right), 1000$ grain weight and grains per $\mathrm{m}^{2}$ were highly correlated with soil removal unlike biomass yield and spikes per $\mathrm{m}^{2}$, which showed no significant correlation. Figure 1 shows the regressions between the main yield components and the different levels of soil removal. The linear function of grain yield and topsoil removal showed a critical drop in wheat productiv- ity. For every $1 \mathrm{~cm}$ of removed topsoil, there was a corresponding decrease of $24 \mathrm{~kg} \mathrm{ha}^{-1}$ in grain yield $\left(\mathrm{R}^{2}=0.75\right)$. The use of fertilisers and manure in high levels masked the low soil productivity. Without fertiliser application, the obtained results indicated low crop yields in a zone resulting from centuries of soil loss events, which has been estimated to be $29.95 \mathrm{Mg}$ ha-1 year-1 (Pérez and González, 2001).
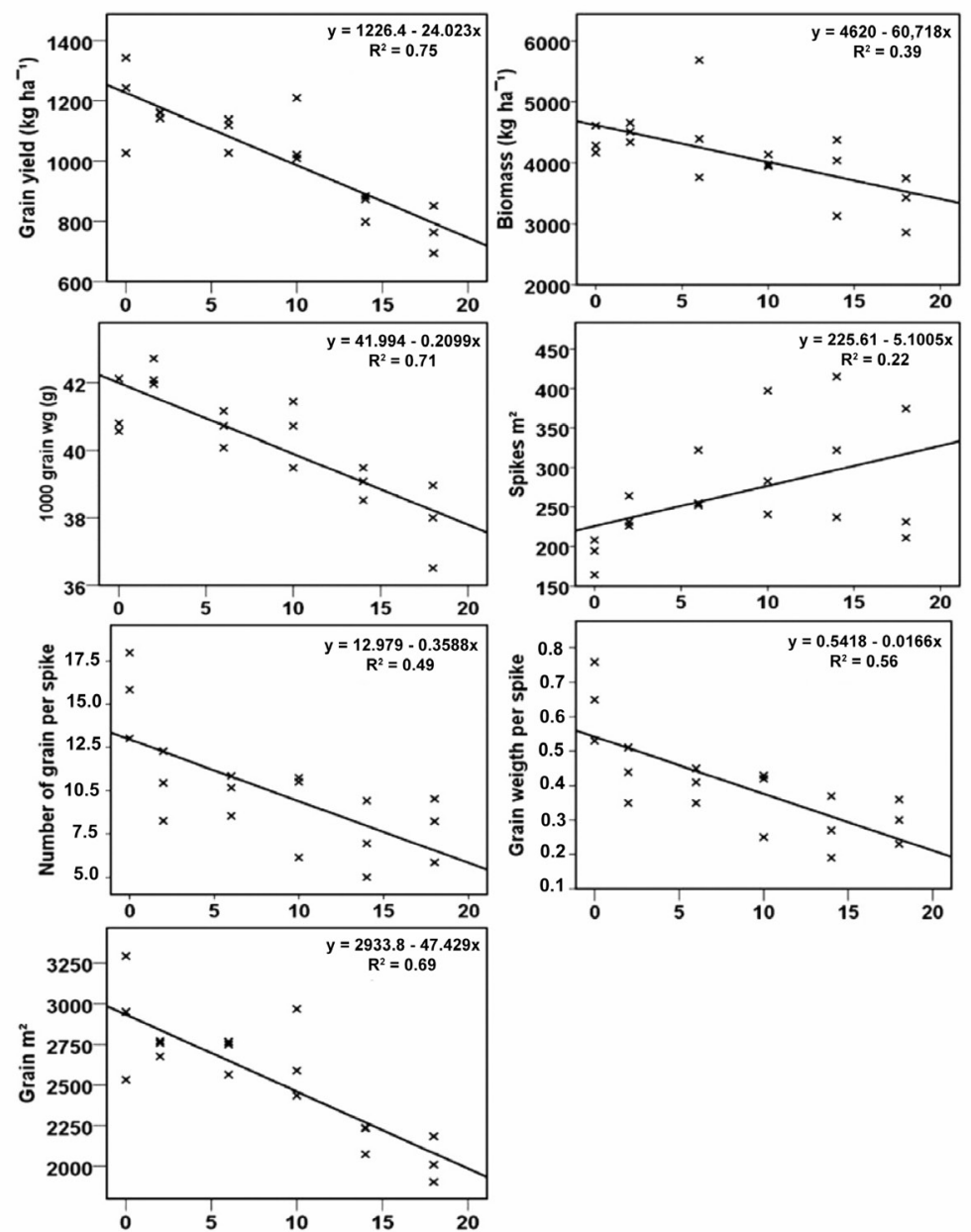

Top soil removal $(\mathrm{cm})$

Figure 1. Correlation plot: productivity parameters vs. topsoil removal. 
As a consequence of topsoil removal, the reduction in grain yield associated with the effect observed for grain weight may be related to a water deficit during the reproductive period, and this impact was higher with more soil removal. The low fertility status and low water retention were magnified by the low organic matter content (Table 5). This is especially critical during the grain filling period, which occurs during a time of higher evapotranspiration demand and lower precipitation occurrence. On the basis of a series of studies, Den Biggelaar et al. (2001) determined that the yield decline in eroded plots in dry years is more significant than in years with abundant rainfall.

Table 5. Soil analysis for treatments after topsoil removal.

\begin{tabular}{|c|c|c|c|c|c|c|c|c|c|c|c|c|c|}
\hline $\mathbf{T}$ & $\mathbf{N}$ & $\mathbf{P}$ & $\mathbf{K}$ & O.M. & pH & Mn & Zn & B & $\mathrm{Ca}$ & Mg & Sand & Silt & Clay \\
\hline $\mathrm{cm}$ & \multicolumn{3}{|c|}{---- $\mathrm{mg} \mathrm{kg}^{-1}$---- } & $\%$ & \multicolumn{4}{|c|}{---------- $\mathrm{mg} \mathrm{kg}^{-1}$} & \multicolumn{2}{|c|}{--- $\mathrm{cmol} \mathrm{kg}^{-1}$--- } & $\%$ & $\%$ & $\%$ \\
\hline$T_{0}$ & 12 & 7 & 96 & 1.60 & 6.22 & 4.03 & 0.50 & 0.34 & 6.32 & 1.81 & 52 & 26 & 23 \\
\hline$T_{2}$ & 10 & 5 & 85 & 1.25 & 6.12 & 3.81 & 0.39 & 0.15 & 7.16 & 1.95 & 51 & 27 & 23 \\
\hline $\mathrm{T}_{6}$ & 8 & 5 & 93 & 1.05 & 6.22 & 3.89 & 0.71 & 0.15 & 6.92 & 1.97 & 50 & 26 & 25 \\
\hline$T_{10}$ & 9 & 5 & 84 & 1.11 & 6.26 & 3.70 & 0.32 & 0.15 & 7.11 & 1.91 & 51 & 25 & 25 \\
\hline$T_{14}$ & 13 & 4 & 74 & 1.05 & 6.31 & 2.21 & 0.25 & 0.16 & 8.13 & 2.33 & 51 & 23 & 27 \\
\hline$T_{18}$ & 11 & 4 & 87 & 0.98 & 6.48 & 1.87 & 0.22 & 0.15 & 10.24 & 3.02 & 45 & 25 & 31 \\
\hline
\end{tabular}

(The following abbreviation is used: OM, organic matter content)

Several factors can affect crop yield as result of the interaction of the effects of topsoil loss. Oyedele and Aina (2006) concluded that the primary impacts of soil removal more significantly affects soil physical properties and organic matter content than other chemical properties. In contrast, other studies conducted on soils to simulate erosion have found that nutrient deficiency is the main factor in yield reduction with drastic changes observed in the chemical properties of soil in relation to the depth of removed soil (Larney et al., 2000; Izaurralde et al., 2006).

As shown in Table 5, the soil analysis after topsoil removal showed that the remaining horizon had lower contents of organic matter and micronutrients, such as $\mathrm{Mn}, \mathrm{Zn}$ and $\mathrm{B}$, as compared with the original soil. These results revealed the preliminary effects of topsoil loss associated with the exposure of the lower horizons. Thus, the impacts of topsoil loss will be even more severe in degraded dryland soils because the upper horizons have already been severely diminished and few fertile materials rise towards the surface. Both of these factors are directly related to the effects of soil erosion (Frye et al., 1982; Larney et al., 1995).

Organic matter content is one of the properties mainly affected by erosion because the concentration of organic carbon is consistently higher in the first 15 $\mathrm{cm}$ of the soil profile (Bauer and Black, 1994). The reduction in organic matter due to topsoil removal and its impact on crop productivity has been documented in other studies (Malhi et al., 1994; Gollany et al., 1992; Izaurralde et al., 2006; Oyedele and Aina, 2006). In terms of soil productivity, Bauer and Black (1994) estimated that the contribution of $1 \mathrm{Mg} \mathrm{ha}^{-1}$ of organic matter in the upper $30.5 \mathrm{~cm}$ is equivalent to 35.2 and $15.6 \mathrm{~kg} \mathrm{ha}^{-1}$ of biomass and grain yield, respectively. In this study, the decrease in organic mat- 
ter content between $\mathrm{T}_{0}$ to $\mathrm{T}_{18}(0.62 \%)$ corresponded to a loss of approximately $15.84 \mathrm{Mg} \mathrm{ha}^{-1}$ between 0 and $18 \mathrm{~cm}$ given that the soil bulk density was equal to $1.42 \mathrm{Mg} \mathrm{m}^{-3}$, which would have a direct impact on crop productivity.

For organic matter and clay percentages, the differences observed were even greater at a depth below $14 \mathrm{~cm}$. The topsoil removal in these treatments $\left(\mathrm{T}_{14^{-}}\right.$ $\mathrm{T}_{18}$ ) resulted in an average decrease in organic matter (36\%) and an increase in clay (19\%). Consistent with data obtained by Gollany et al., (1992), the increment in clay content in $\mathrm{T}_{18}$ can be explained by the exposure of the $\mathrm{Bw}_{1}$ horizon of the original pedon. In turn, the increase in the clay fraction may be associated with the higher concentrations of $\mathrm{Ca}^{2+}$ and $\mathrm{Mg}^{2+}$ ions in the soil, which may explain the increase of these exchange bases deeper within the profile. Despite that topsoil loss due to water erosion is imperceptible each year and is not a uniform phenomenon, the result of this study demonstrated that the low crop productivity in the study area is due to hundreds of years of soil degradation.

\section{Conclusions}

In this study, the wheat grain yield had a proportional decreasing trend with respect to the levels of soil removed. However, the results obtained for one growing season only presented statistical differences for excessive soil loss ( $\left.>2000 \mathrm{Mg} \mathrm{ha}^{-1}\right)$. Removal of 18 centimetres of soil resulted in the loss of a fertile layer within the soil profile $(0-15 \mathrm{~cm})$, which was reflected by a $36 \%$ reduction in organic matter content in this study. The effects on the physical properties of soil, mainly on available water storage, are factors that influence this relationship, and these effects must be evaluated. Similarly, agroclimatic conditions, especially rainfall patterns, may also have an impor- tant role in establishing the shape of this function. In general, these results obtained from dryland areas in Central Chile highlighted the importance of topsoil where physical, chemical and microbiological factors may be critical in defining the decay function of crop productivity and soil loss.

\section{Acknowledgements}

This research was funded by the Dirección de Investigación y Perfeccionamiento de la Universidad Católica del Maule. The authors thank Dr. Oscar Seguel from the Universidad de Chile and Dr. Iván Matus from INIA Quillamapu for their selfless support of the investigation. The authors would also like to thank the Centro de Desarrollo del Secano Interior from UCM for their technical support.

\section{References}

Bakker, M., Govers, G., Rounsevell, M. 2004. The crop productivity-erosion relationship: an analysis based on experimental work. Catena 57, 55-76.

Bauer, A., Black, A. 1994. Quantification of the effect of soil organic matter content on soil productivity. Soil Sci. Soc. Am. J. 58, 185-193.

CIREN. 1997. Descripciones de suelos, materiales y símbolos. Estudio Agrológico VII Región. Publicación $N^{\circ} 117$. Centro de Información de Recursos Naturales. Chile. 659 p.

Christensen, L., McElyea, D. 1988. Toward a general method of estimating productivity-soil depth response relationships. J. Soil Water Cons. 43, 199202.

Den Biggelaar, C., Lal, R., Wiebe, K., Breneman, V. 2001. Impact of soil erosion on crop yields in North America. Adv. Agron. 72, 1-52. 
Fenton, T. E., Kazemi, M., Lauterbach-Barrett, M. 2005. Erosional impact on organic matter content and productivity of selected Iowa soils. Soil Till Res. 81, 163-171.

Flörchinger, F. A., Leihner, D. E., Steinmüller, N., Müller-Sämann, K., El-Sharkkawy, M. 2000. Effects of artificial topsoil removal on Sorghum, Peanut, and Cassava yield. J. Soil Water Cons. 55, 334-339.

Frye, W. W., Ebelhar, S. A., Murdock, L. W., Blevins, R. L. 1982. Soil erosion effects on properties and productivity of two Kentucky soil. Soil Sci. Soc. Am. J. 46, 1051-1055.

Gollany, H. T., Schumacher, T. E., Lindstrom, M. J., Evenson, P. D., Lemme, G. D. 1992. Topsoil depth and desurfacing effects on properties and productivity of a typic argiustoll. Soil Sci. Soc. Am. J. 56, 220-225.

Hairston, J. E., Sanford, J. O., Rhoton, F. E., Miller, J. G. 1988. Effect of soil depth and erosion on yield in the Mississippi blacklands. Soil Sci. Soc. Am. J. 52, 1458-1463.

Izaurralde, R. C., Malhi, S. S., Nyborg, M., Solberg, E. D., Quiroga, M. C. 2006. Crop performance and soil properties in two artificially eroded soil in North-Central Alberta. Agron. J. 98, 1298-1311.

Larney, F. J., Izaurralde, R. C., Janzen, H. H., Olson, B. M., Solberg, E. D., Lindwall, C. W., Nyborg, M. 1995. Soil erosion-crop productivity relationships for six Alberta soils. J. Soil Water Cons. 50, 87-91.

Larney, F. J., Olson, B. M., Janzen, H. H., Lindwall, C. W. 2000. Early impact of topsoil removal and soil amendments on crop productivity. Agron. J. 92, 948-956.

Larney, F. J., Janzen, H. H., Olson, B. M., Olson, A. F. 2009. Erosion-productivity-soil amendment relationships for wheat over 16 years. Soil Till Res. 103, 73-83.
Malhi, S., Izaurralde, R., Nyborg, M., Solberg, E. 1994. Influence of topsoil removal on soil fertility and barbey growth. J. Soil Water Cons. 49, 96101.

Mellado, M. 2007. El trigo en Chile. Cultura, ciencia y tecnología. INIA N $N^{0} 21$. Instituto de Investigaciones Agropecuarias. Chile. 684 p.

Mielke, L. N., Schepers, J. S. 1986. Plant response to topsoil thickness on an eroded loess soil. J. Soil Water Cons. 41, 59-63.

Oyedele, D. J., Aina, P. O. 2006. Response of soil properties and maize yield to simulated erosion by artificial topsoil removal. Plant and Soil. 284, 375-384.

Pérez, C., González, J. 2001. Diagnóstico sobre el estado de degradación del recurso suelo en el país. Boletín INIA $\mathrm{N}^{\circ} 15$. Instituto de Investigaciones Agropecuarias. Chile. 196 p.

Power, J. F., Sandoval, F. M., Ries, R. E., Merrill, S. D. 1981. Effects of topsoil and subsoil thickness on soil water content and crop production on a disturbed soil. Soil Sci. Soc. Am. J. 45, 124-129.

Sadzawka, A., Grez, R., Mora, M., Saavedra, N., Carrasco, A. 2001. Métodos de análisis de tejidos vegetales. Comisión de Normalización y Acreditación Sociedad Chilena de la Ciencia del Suelo. Chile. 35 p.

Sadzawka, A., Carrasco, M., Grez, R., Mora, M., Flores, H., Neaman, A. 2006. Métodos de análisis recomendados para los suelos de Chile. Serie $\mathrm{N}^{\circ}$ 30. Centro Regional de Investigación. Chile. 164 p.

Tanaka, D. L., Aase, J. K. 1989. Influence of topsoil removal and fertilizer application on spring wheat yields. Soil Sci. Soc. Am. J. 53, 228-232.

Thompson, A. L., Gantzer, C. J., Anderson, S. H. 1991. Topsoil depth, fertility, water management and weather influences on yield. Soil Sci. Soc. Am. J. 55, 1085-1091. 
